\title{
Correlation of Neuroendocrine Differentiation with Neuroendocrine Cell Hyperplasia and Vascular Endothelial Growth Factor in Colorectal Adenocarcinoma
}

\author{
Khesar H. Khalil ${ }^{1 *}$ \\ Bashar A. Al-Hassawi ${ }^{1}$ \\ Jasim M. Abdo ${ }^{2}$ \\ ${ }^{1}$ Department of Anatomy, Biology and Histology, College of Medicine, University of Duhok, Duhok ,Iraq \\ ${ }^{2}$ Department of Clinical Pharmacology, College of Pharmacy, University of Duhok, Duhok ,Iraq \\ *Corresponding author: khesar.hussein@uod.ac*, bashar.ibrahim@uod.ac, dr.jassim@uod.ac \\ *ORCID ID: https://orcid.org/0000-0003-2327-1703, https://orcid.org/0000-0002-9739-8726, https://orcid.org/0000- \\ $\underline{0003-1769-622 X}$
}

Received 1/9/2019, Accepted 13/2/2020, Published Online First 6/12/2020, Published 1/3/2021

This work is licensed under a Creative Commons Attribution 4.0 International License.

\begin{abstract}
:
Neuroendocrine differentiation has been mentioned in many cancers of non-neuroendocrinal organs, involving the gastrointestinal tract. In contrast, the correlation of focally diffused neuroendocrine differentiation in colorectal adenocarcinoma with neuroendocrine cell hyperplasia has not been somewhat reported. The objective of this research is to study the relationship between neuroendocrine cell hyperplasia and neuroendocrine differentiation in colorectal adenocarcinoma and to find the correlation of neuroendocrine differentiation and VEGF expression with clinicopathological parameters of colorectal adenocarcinoma. Methods employed in the current study were including eighty-one patients with colorectal cancer. Formalin fixed paraffin embedded blocks were sectioned and stained with immunohistochemical markers; Chromogranin A and VEGF; and processed automatically according to protocols supplied by the antibody manufacturer. Results show that neuroendocrine cell hyperplasia in the mucosa nearby tumor comprised (42\%) and it was associated with neuroendocrine differentiation. Neuroendocrine differentiation and vascular endothelial growth factor were positive in $48.1 \%$ and $63 \%$ respectively. Neuroendocrine differentiation did not show a relation with clinicopathological parameters with the exception of tumor that metastasizes to other tissues and organs. The association of VEGF with the same factors had significant impact with tumor stage, degree of local invasion and lymph node metastasis. Other histological changes revealed that only desmoplastic reaction had significant difference in relation to neuroendocrine differentiation. This study reached the conclusion that neuroendocrine cell hyperplasia is positively correlated with neuroendocrine differentiation and it has strong linkage in pathogenesis of colorectal adenocarcinoma. Neuroendocrine differentiation and VEGF expression are greatly correlated with progression and invasion of tumor to other tissues and organs, and this can be represented as an important parameter for poor prognosis of colorectal adenocarcinoma.
\end{abstract}

Key words: Colorectal adenocarcinoma, Neuroendocrine cell hyperplasia, Neuroendocrine differentiation, Vascular endothelial growth factor (VEGF).

\section{Introduction:}

Colorectal cancer (CRC) is the third most popular cancer and occupies the fourth death rate related to cancer (1). The majority of patients with $\mathrm{CRC}$ are detected in Western countries and they are increasing in the incidence annually. Few percentages near about $4 \%-5 \%$ of people may be suffering from CRC. The risk factors to develop the disease are related to personal features or habits such as age, lifestyle and chronic disease history (1).
Neuroendocrine cells are located in several organs of the body such as the gastrointestinal tract, pancreas, adrenal gland, thyroid, and lung. The gastrointestinal tract occupies the major part of neuroendocrine cells. These cells produce peptides or amines and were previously referred to as aminoprecursor-uptake-decarboxylation (APUD) cells. They are diffusely distributed throughout the body tissues and belong to the diffuse neuroendocrine system (DNES). The functions of neuroendocrine system in the normal gastrointestinal tract is 
controlling the proliferation and the growth of epithelial and mesenchymal cells and probably sense the person feeling of hunger during fasting and food-intake (2).

Neuroendocrine cells are well-documented to play a role in the proliferative compartments of gut and gastrointestinal adenocarcinomas (AD) (3, 4). Neuroendocrine differentiation (NED) has been mentioned in many cancers of non-neuroendocrinal organs, involving the gastrointestinal tract $(3,5)$. Several studies have been conducted in CRC to assess the NED for years ago, but the clinical effect is controversial (3).

The neuroendocrine cell (NE cell) hyperplasia is considered the precursor's lesion in the gastrointestinal and pancreatic neuroendocrine tumors (GEP-NETs). In the large bowel, this condition is described as an inflammatory bowel disease in which it has neither a genetic nor a definite hormonal background (6).

Hyperplasia of the endocrine cell is defined when more than 5 cells are found per gland, at least 2 linear chains/ $\mathrm{mm}$ or one micronodule less than $150 \mu \mathrm{m} / \mathrm{mm}$ (1 micronodule per millimeter length of mucosa). Basically, it starts as a proliferative growth with linear arrangement and then a micronodular arrangement which results in extraglandular nodular growth leading to multiple NETs $(6,7)$.

Mixed adenoneuroendocrine carcinomas were described in gastrointestinal neoplasm according to recent World Health Organization (WHO) classification (8). High-grade NET may be noticed in the large bowel with conventional cancer (adenoma/ adenocarcinomas or squamous cell carcinoma in the anal canal) (9). However, a possible link between NE cell hyperplasia to the focal diffused NED and transition from adenoma to carcinoma has not been somewhat reported.

One of the growth factors in gastrointestinal cancer is VEGF, the pro-angiogenic factor that has been identified to regulate angiogenesis (10). Growth factors production such as VEGF, TGF-a, PDGF, HGF, TGF-b1, and CTGF, has been well defined in NE-cell NETs. These growth factors provide the structural framework for the desmoplastic reaction mentioned in the mesentery, the blood vessels, which lead to the symptoms observation $(11,12)$. Evidence from preclinical and clinical studies demonstrates that VEGF is considered the prominent factor that participates in CRC angiogenesis and it has a great correlation with NED and progression of disease $(13,14)$.

Vascular endothelial growth factor A (VEGF-A) which is considered the most prominent member of the VEGF family, is a heparin-binding glycoprotein that has a potent mediator for angiogenesis. It promotes vascular permeability of endothelial cells for neoplastic cells (15).

This study is conducted to:

1. Study the relationship between neuroendocrine cell hyperplasia and neuroendocrine differentiation in colorectal $\mathrm{AD}$.

2. Find the correlation of neuroendocrine differentiation and VEGF expression with clinicopathological and different histological parameters in colorectal $\mathrm{AD}$.

\section{Materials and Methods: Sampling:}

Eighty one formalin fixed paraffin embedded blocks of CRC tissues were collected during the period from January 2015 to December 2017 from the histopathology department of Central Public Health Laboratory and other private laboratories in Duhok Governorate. The study was conducted after approval of the research ethics committee in Duhok Directorate General of Health. The age and gender of the patients, grading and staging of the tumor and histopathological findings were recorded for each case. No patient received chemotherapy. Classification of tumor was done according to WHO classifications (7).

\section{Histopathology and Immunohistochemistry (IHC):}

Tissues sections 4 microns were mounted on salinized slides (Dako, Denmark) then deparaffinized, after that they were rehydrated in ethanol through descending concentrations. Chromogranin A (CGA) was used as a neuroendocrine differentiation marker (16), and VEGF as angiogenic factor. IHC staining was performed with anti-CGA antibody (Polyclonal Rabbit Anti-Human Chromogranin A) (Code No: A 0430; Dilution 1/400; DakoCytomation, USA) and anti-VEGF antibody (Monoclonal Mouse Antibody; Code No: MA5-13182; clone JH121, dilution 1/50; Thermo Fisher Scientific, USA). The pre-treatment with heat-induced epitope retrieval (HIER) was done using EnVision FLEX Target Retrieval Solution and Dako PT Link (Code PT100/PT101).

Slides were processed automatically (Autostainer link 48; Dako, Denmark) according to the protocols supplied by the antibody manufacturers with the following reagents: EnVision FLEX Peroxidase Blocking reagent, primary antibody, secondary antibody for both markers (anti-CGA antibody and anti-VEGF antibody) and 3,30- Diaminobenzidine (DAB+) chromogen then hematoxylin and eosin. The staining steps and incubation times were preprogrammed into the Autostainer Link software. 
The recommended reagent application volume was $1 \times 200 \mu \mathrm{L}$ per slide.

When the staining procedure was completed, the slides were dehydrated, cleared then mounted. The immuno-reactive evaluation for both markers was assessed. The antibody of CGA labels chromogranin A found in secretory granules in the cytoplasm of NE cells; VEGF antibody labels mainly the cytoplasm of tumor cells; therefore, the presence of a brown cytoplasmic reaction indicated positive reaction for both immunostaining markers, and otherwise the reaction was considered negative. Scoring:

Tumor regions containing CGA positive cells were identified with low power (100x and 400x) microscopy. Normal mucosal cells of the colon containing neuroendocrine cells were used as positive internal controls for CGA reactivity as well as for detection neuroendocrine cells hyperplasia.

Scoring of CGA immuno-reactivity in tumor tissue was done according to a modified three-tier system determined by Shia et al. (17) including score 0 : no staining in tumor cells; score $1+:>0$ and $<30 \%$ of tumor cells stained, and score $2+: \geq 30 \%$ of tumor cells stained. Sections with score 1 and score 2 were estimated as positive expression for CGA and they behaved as positive $\mathrm{NED}$, and score 0 was considered negative for CGA expression.

Expression of VEGF was based on the staining intensity of the malignant epithelial cells. Endothelial cell, fibroblastic or other stromal cells staining were not considered during the assessment. Smooth muscle cells were used as positive internal controls for VEGF immuno-reactivity. The degree of VEGF expression was grouped into three categorizations according to the percentage of immuno-reactive cells, the positive staining cells over the total number of counted cells, as follows; score 0 : the staining intensity of malignant epithelial cells were less than the staining intensity of normal smooth muscle; score 1: $<30 \%$ of malignant epithelial cells were stained with similar intensity to that of normal smooth muscle, and score $2: \geq 30 \%$ of malignant epithelial cells were stained more intensely than normal smooth muscle. The final two scores were considered positive expression (18).

\section{Statistical Analysis:}

Results were analyzed using the Social Sciences Statistical Package, version 16 (SPSS Software, SPSS Inc., Chicago, USA). Descriptive analysis of data was carried out using the frequencies of the relevant data.

Possible relation between NE cell hyperplasia and NED; clinicopathological parameters relation with NED, and VEGF were investigated using Chi square or Fisher's exact probability test. Statistical significant was regarded a pvalue of less than 0.05. Pearson Correlation (2tailed) test has been used to correlate the histological changes with NED and VEGF.

\section{Results:}

Eighty one patients (52 males and 29 females) were diagnosed with CRC. The mean age was 53.65 years (range: 18-83 years). Regarding the grading of $\mathrm{CRC}$, well and poor differentiated $\mathrm{AD}$ were the less common comprising $2(2.5 \%)$ and $8(9.9 \%)$ respectively, the remaining 71 cases (87.7) were moderately differentiated. The histological findings revealed that 65 cases $(80.2 \%)$ of conventional type while the remaining types included mucinous with 11 cases (13.6\%) and signet ring cell 5 cases only (6.2\%). The majority of patients 44 cases $(54.3 \%)$ had stage III, and those with stage IV were the least comprising 4 cases (4.9\%). Nearly half of cases $41(50.6 \%)$ were recorded with colon cancer whereas rectal cancer represented the other half number of cases 40 (49.4\%) (Table 1).

Table 1. Frequency and percentage of clinicopathological factors for CRC patients

\begin{tabular}{ccc}
\hline Parameter & Findings & Frequency (\%) \\
\hline Gender & Male & $52(64.2)$ \\
& Female & $29(35.8)$ \\
Age & $<60$ & $41(50.6)$ \\
& $\geq 60$ & $40(49.4)$ \\
Tumor site & Colon & $41(50.6)$ \\
& Rectum & $40(49.4)$ \\
Histological & Conventional & $65(80.2)$ \\
type of & Mucinous & $11(13.6)$ \\
tumor & Signet ring cell & $5(6.2)$ \\
Grade & Well & $2(2.5)$ \\
& Moderate & $71(87.7)$ \\
& Poor & $8(9.9)$ \\
& I & $9(11.1)$ \\
TNM Stage & II & $24(29.6)$ \\
& III & $44(54.3)$ \\
& IV & $4(4.9)$ \\
Local & T2 & $12(14.8)$ \\
Invasive & T3 & $64(79.0)$ \\
Depth & T4 & $5(6.2)$ \\
Lymph & N0 & $34(42.0)$ \\
Nodes & N1 \& N2 & $47(58.0)$ \\
Distant & M0 & $77(95.1)$ \\
Metastasis & M1 & $4(4.9)$ \\
& Total & \\
\hline
\end{tabular}




\section{Immunohistochemistry findings:}

The expression of IHC marker CGA was used for NED and NE cell hyperplasia. From the total number (81) of patients about half of them 39 cases $(48.1 \%)$ showed positive NED in tumor cells (Fig. 1). The other cases 42 (51.9\%) had negative expression of NED.

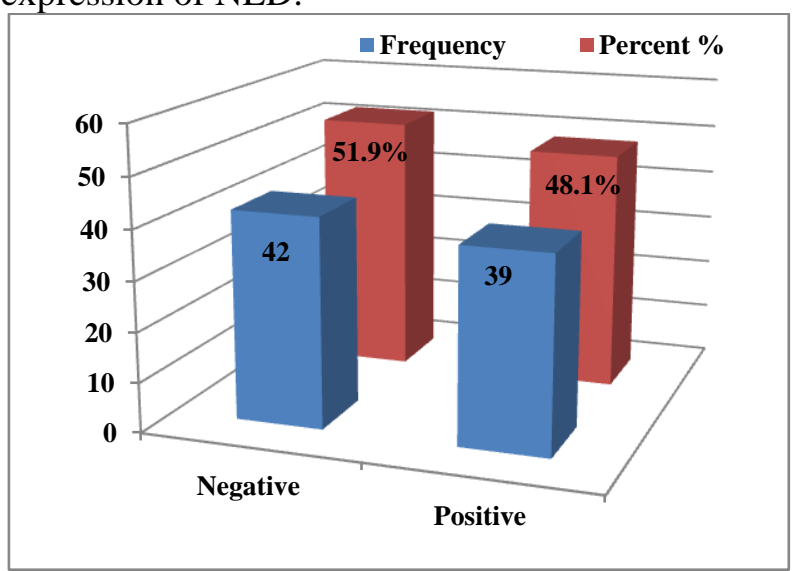

Figure 1. Frequency and percentage of NED using IHC marker (CGA) in CRC patients.

The frequency of positive NE cell hyperplasia was found in 34 cases $(42 \%)$. The other cases had the normal percentage of enteroendocrine

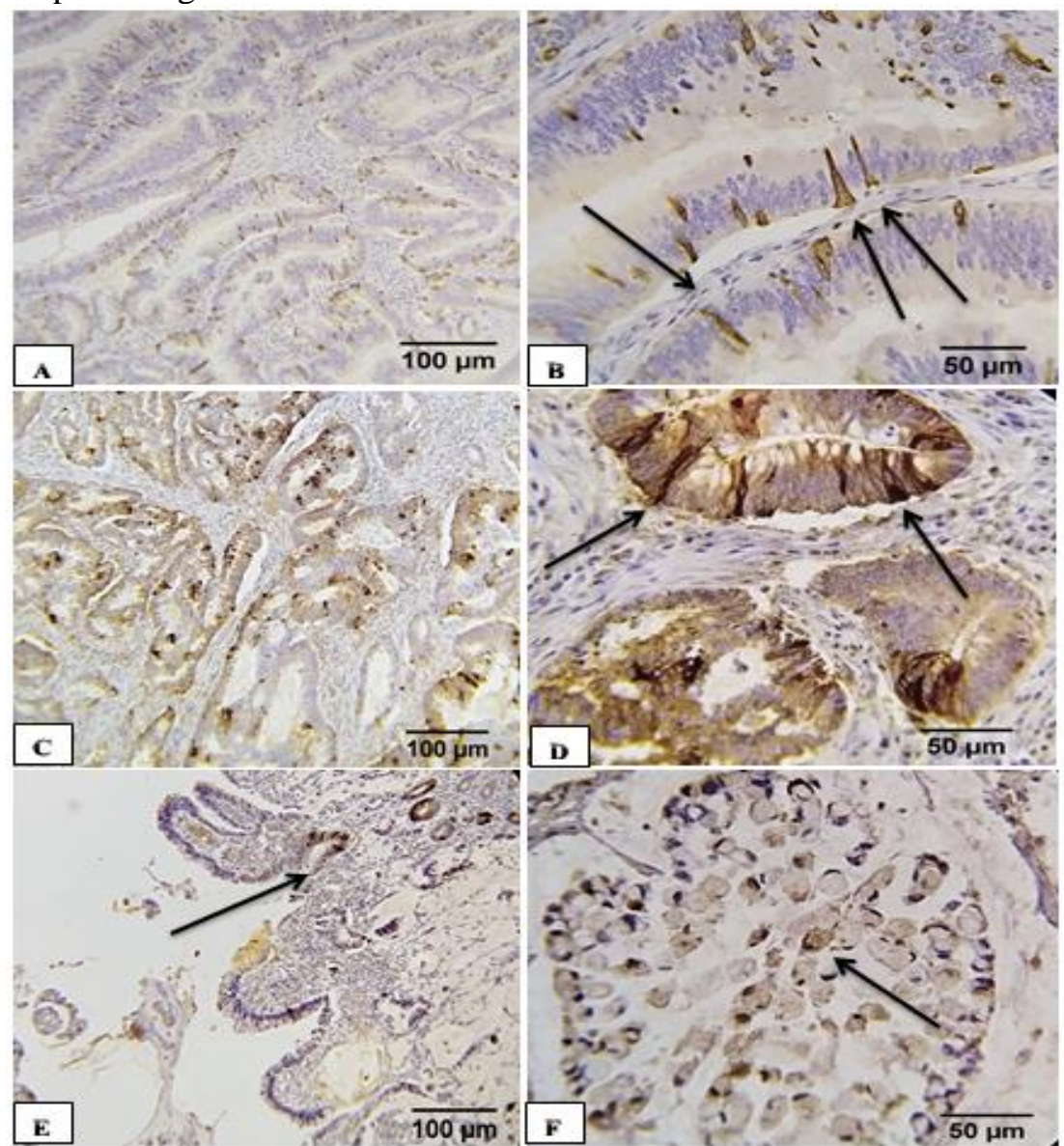

Figure 3. Colorectal AD with positive NED in histological types: conventional AD with scale bar 100 $\mu \mathrm{m}(\mathrm{A} \& \mathrm{C})$, conventional AD with scale bar $50 \mu \mathrm{m}$ observing $\mathrm{NE}$ cells within glands of tumor (arrow) (B \& D), in mucinous AD with scale bar $100 \mu \mathrm{m}$, the NE cells also found in glandular tumor (E) signet ring cell AD (arrow) with scale bar $50 \mu \mathrm{m}(\mathrm{F})$, these cells had positive CGA stain. cells; i.e. they were negative for NE cell hyperplasia in 47 cases (58\%) (Fig. 2).

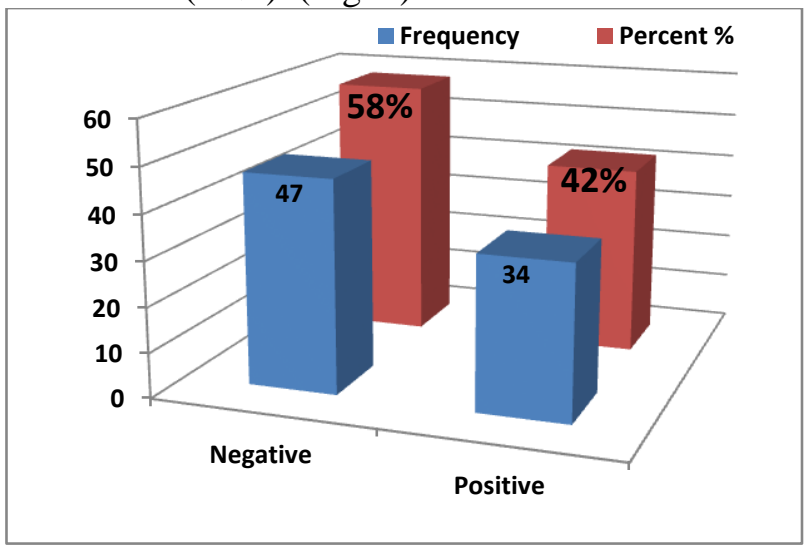

Figure 2. Frequency and percentage of $\mathrm{NE}$ cell hyperplasia using IHC marker (CGA) in CRC patients.

The expression of NED appears in all histological types of CRC (Fig. 3). In conventional $\mathrm{AD}$, the NED was observed in the cytoplasm of glandular tumor cells (Fig.3 A, B, C \& D). Signet ring cell and mucinous $\mathrm{AD}$ also had positive NED (Fig.3 E \& F). 
The colorectal mucosa nearby the tumor revealed negative NE cell hyperplasia. Negative NE cell hyperplasias have the same behavior as the normal mucosal samples with the normal percentage $(1 \%)$ of enteroendocrine cells within glandular epithelium of the normal colon as shown

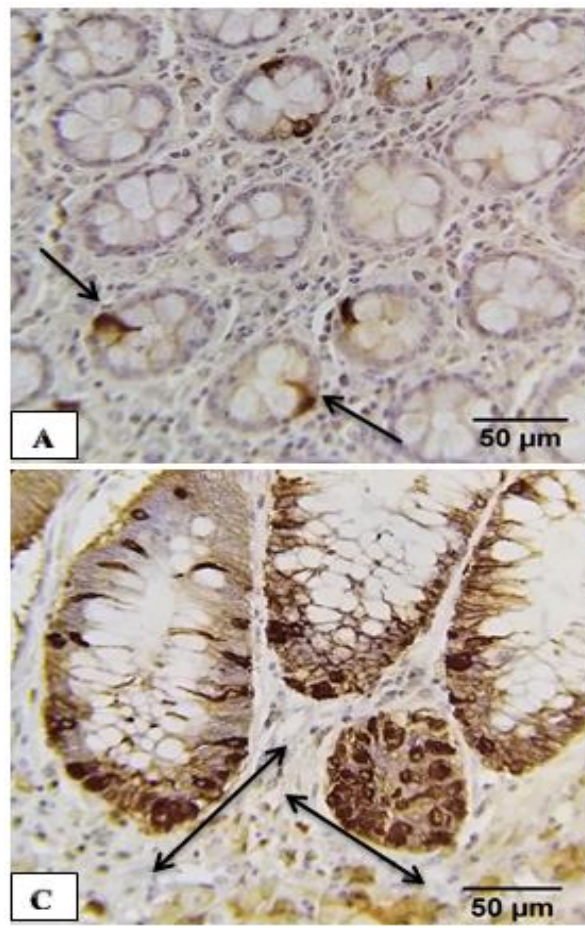

in (Fig. 4 A). The increasing numbers of NE cells in normal mucosal layer nearby the tumors (hyperplasia) were found in (Fig. 4 B, C \& D). These cells containing more than 5 cells per gland, or at least two linear chains / $\mathrm{mm}$ or one micronodule.

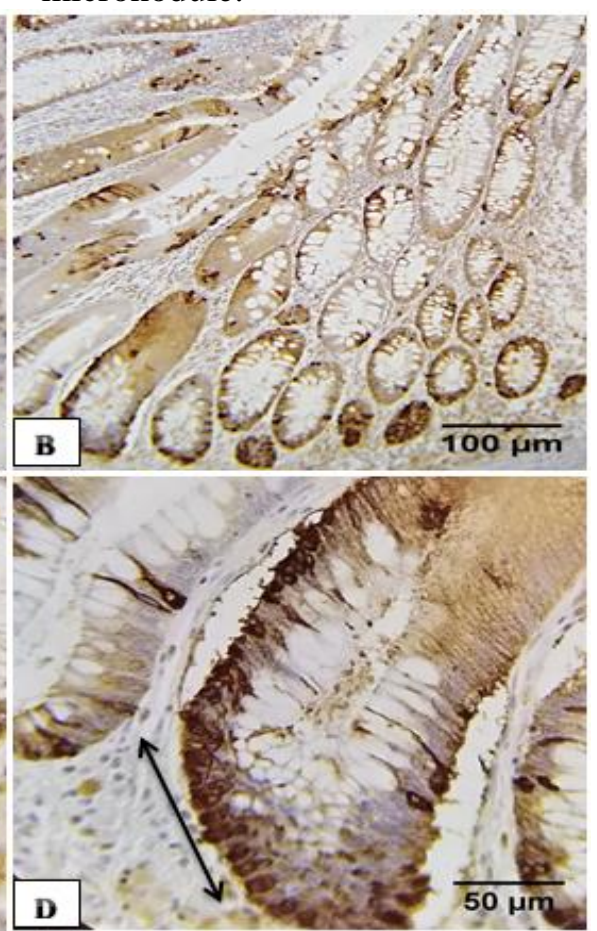

Figure 4. NE cell (arrow) in normal colonic mucosa nearby carcinoma with scale bar $50 \mu \mathrm{m}$ (A). Colonic mucosa with NE cell hyperplasia with scale bar $100 \mu \mathrm{m}(B)$, NE cell hyperplasia; (double head arrow) are these cells containing more than 5 cells per gland, or at least 2 linear chains/mm or one micronodule, scale bar $50 \mu \mathrm{m}(\mathrm{C} \& \mathrm{D})$.

Table 2 demonstrates the relationship of NE cell hyperplasia with NED. Thirty seven out of 47 cases revealed negative expression of CGA in normal and tumor cells. By contrast, 29 cases from 34 had positive CGA expression in both normal and tumor cells. The increasing number of NE cells in normal mucosal layer nearby the tumors (hyperplasia) seemed to have a significant relationship $\left(\mathrm{P}<0.001^{* *}\right)$ with NED in CRC.

Table 2. Relation of NE cell hyperplasia with NED

\begin{tabular}{|c|c|c|c|c|c|c|c|}
\hline \multirow{3}{*}{ NE cell Hyperplasia } & \multicolumn{4}{|c|}{ NED } & \multirow{2}{*}{\multicolumn{2}{|c|}{ Total }} & \multirow{3}{*}{ P-value } \\
\hline & \multicolumn{2}{|c|}{ Positive } & \multicolumn{2}{|c|}{ Negative } & & & \\
\hline & No. & $\%$ & No. & $\%$ & No. & $\%$ & \\
\hline Negative & 10 & 12.3 & 37 & 45.7 & 47 & 58.0 & ( \\
\hline Positive & 29 & 35.8 & 5 & 6.2 & 34 & 42.0 & 0.001 \\
\hline Total & 39 & 48.1 & 42 & 51.9 & 81 & 100 & \\
\hline
\end{tabular}

* Chi square. P-value is significant, $P \leq 0.05$

Table 3 shows the absence of correlation between clinicopathological factors and NED, with the exception of tumor that metastasizes to other tissues and organs (distant metastasis) $(\mathrm{P}=0.049)$. Also, there is relative correlation between local invasion beyond the mucosal wall, lymph node invasion and increasing CGA expression, but this increase was statistically non-significant. Among 65 cases from conventional $\mathrm{AD}, 31$ cases $(79.5 \%)$ had positive NED. In mucinous and signet ring cell $A D$ half of cases showed positive NED. Regarding the grade of tumor, it did not show any correlation with the NED. 
Table 3. Association the clinicopathological findings with NED in CRC.

\begin{tabular}{|c|c|c|c|c|c|c|c|c|}
\hline \multirow{3}{*}{\multicolumn{2}{|c|}{ Histopathological Finding }} & \multicolumn{4}{|c|}{ NED } & \multirow{2}{*}{\multicolumn{2}{|c|}{ Total }} & \multirow{3}{*}{ P-value } \\
\hline & & \multicolumn{2}{|c|}{ Positive } & \multicolumn{2}{|c|}{ Negative } & & & \\
\hline & & No. & $\%$ & No. & $\%$ & No. & $\%$ & \\
\hline & Male & 23 & 59.0 & 29 & 69.0 & 52 & 64.2 & $0.345^{*}$ \\
\hline Gender & Female & 16 & 41.0 & 13 & 31.0 & 29 & 35.8 & \\
\hline \multirow[t]{3}{*}{ Age } & $<60$ & 24 & 61.5 & 17 & 40.5 & 41 & 50.6 & $0.058 *$ \\
\hline & $\geq 60$ & 15 & 38.5 & 25 & 59.5 & 40 & 49.4 & \\
\hline & Colon & 20 & 51.3 & 21 & 50.0 & 41 & 50.6 & $0.908 *$ \\
\hline \multirow[t]{2}{*}{ Tumor site } & Rectum & 19 & 48.7 & 21 & 50.0 & 40 & 49.4 & \\
\hline & Conventional AD & 31 & 79.5 & 34 & 81.0 & 65 & 80.2 & $0.918 * *$ \\
\hline Histological & Mucinous AD & 6 & 15.4 & 5 & 11.9 & 11 & 13.6 & \\
\hline \multirow[t]{2}{*}{ Types } & Signet ring cell AD & 2 & 5.1 & 3 & 7.1 & 5 & 6.2 & \\
\hline & Well & 1 & 2.6 & 1 & 2.4 & 2 & 2.5 & \\
\hline \multirow[t]{3}{*}{ Grade } & Moderate & 33 & 84.6 & 38 & 90.5 & 71 & 87.7 & $0.733 * *$ \\
\hline & Poor & 5 & 12.8 & 3 & 7.1 & 8 & 9.9 & \\
\hline & I & 2 & 5.1 & 7 & 16.7 & 9 & 11.1 & $0.062 * *$ \\
\hline \multirow[t]{3}{*}{ TNM Stage } & II & 10 & 25.6 & 14 & 33.3 & 24 & 29.6 & \\
\hline & III & 23 & 59.0 & 21 & 50.0 & 44 & 54.3 & \\
\hline & IV & 4 & 10.3 & 0 & 0 & 4 & 4.9 & \\
\hline Local Invasive & $\mathrm{T} 2$ & 4 & 10.3 & 8 & 19.0 & 12 & 14.8 & $0.239 * *$ \\
\hline \multirow[t]{2}{*}{ Depth } & $\mathrm{T} 3$ & 31 & 79.5 & 33 & 78.6 & 64 & 79.0 & \\
\hline & $\mathrm{T} 4$ & 4 & 10.3 & 1 & 2.4 & 5 & 6.2 & \\
\hline \multirow[t]{2}{*}{ Lymph Nodes } & Non involved & 13 & 33.3 & 21 & 50.0 & 34 & 42.0 & $0.129 *$ \\
\hline & Involved & 26 & 66.7 & 21 & 50.0 & 47 & 58.0 & \\
\hline Distant & M0 & 35 & 89.7 & 42 & 100 & 77 & 95.1 & $0.049 * *$ \\
\hline Metastasis & M1 & 4 & 10.3 & 0 & 0 & 4 & 4.9 & \\
\hline \multicolumn{2}{|c|}{ Total } & 39 & 100 & 42 & 100 & 81 & 100 & \\
\hline
\end{tabular}

* Chi square, **Fisher exact test. P-value is significant, $P \leq 0.05$

Expression of VEGF in CRC was positive in 51 cases $(63 \%)$, whereas the other 30 cases $(37 \%)$ displayed negative expression (Fig. 5).

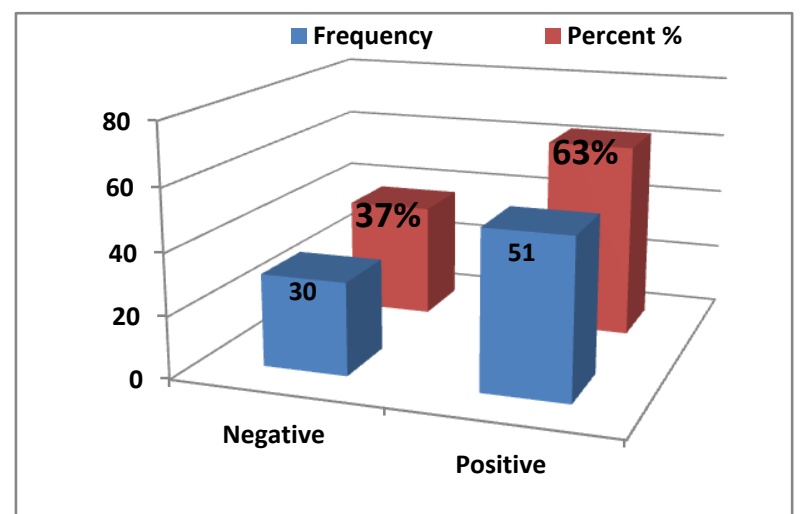

Figure 5. Frequency and percentage of VEGF expression in CRC patients.
VEGF showed negative expression in the cytoplasm of tumor cells in conventional AD (Fig. 6 A). Positive expression of VEGF was found in the cytoplasm of tumor cells in conventional AD (Fig. 6 $\mathrm{B} \& \mathrm{C}$ ) and in signet ring cell $\mathrm{AD}$ (Fig. $6 \mathrm{D}$ ). 


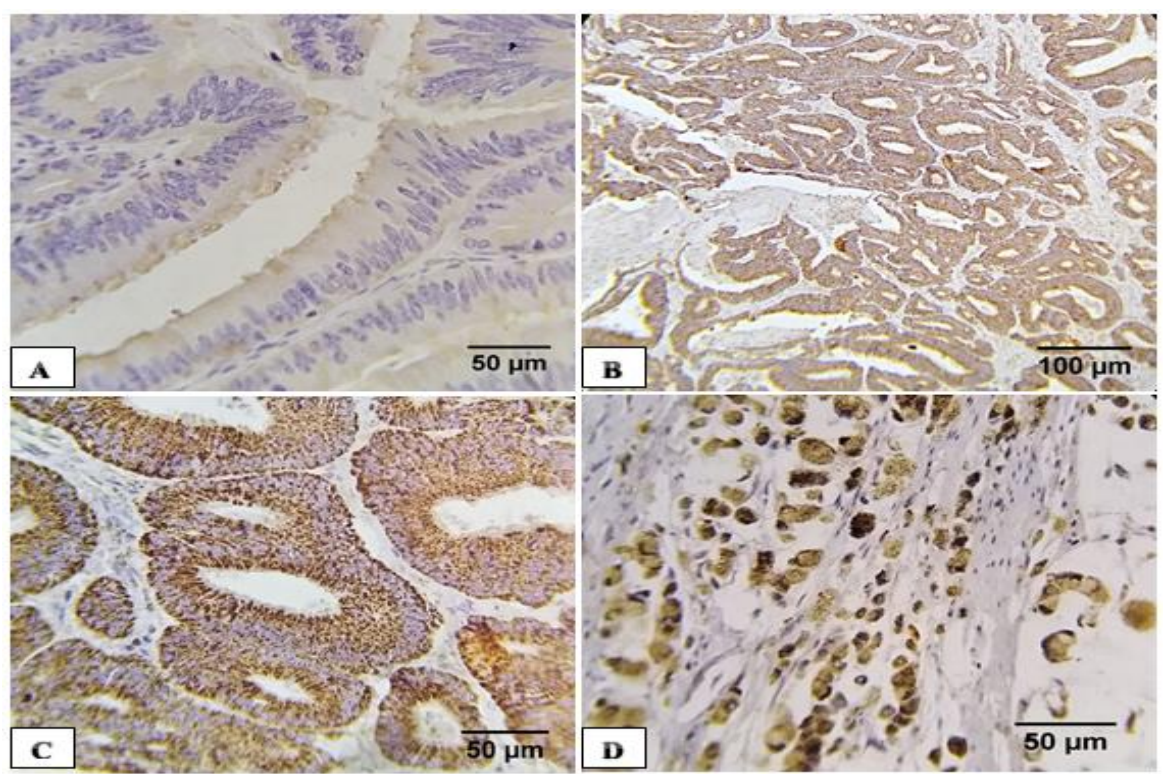

Figure 6. Colorectal AD with VEGF expression in: Conventional AD had negative expression, scale bar $50 \mu \mathrm{m}(\mathrm{A})$, conventional AD with strong expression, scale bar $100 \mu \mathrm{m}(\mathrm{B})$, conventional AD with positive expression in cytoplasmic granules within tumor cells, scale bar $50 \mu \mathrm{m}(\mathrm{C})$, signet ring cell AD with strong expression of VEGF, scale bar $50 \mu \mathrm{m}$ (D).

The clinicopathological findings association with VEGF expression is manifested in Table 4. None of the gender, age, and tumor site has a relation with VEGF expression. All cases of signet ring cell 5 cases $(9.8 \%)$ revealed positive VEGF expression. About two third of mucinous AD cases (8 out of 11) had positive expression for the VEGF. Conventional AD of CRC revealed high positivity rate of VEGF 38 cases with the percentage of $(74.5 \%)$. The variation in expression of VEGF among histological type did not show any significant effect. VEGF is highly expressed within each group of tumor grade without any statistical significant. Expression of VEGF showed great relationship with TNM stage, it increased toward the progression of tumor stage $(\mathrm{P}=0.006)$. This means that only one case in stage I had positive expression of VEGF, whereas in stage II and III the expression of VEGF increased as $16(31.4 \%)$ and $31(60.8 \%)$ respectively. The majority, 3 cases out of 4 of stage IV were positive for VEGF. Local invasion to the colorectal wall $(\mathrm{P}=0.001)$ as well as lymph node invasion $(\mathrm{P}=0.040)$ were expressed VEGF with statistical significant.

Table 4. Association the clinicopathological findings with VEGF expression in CRC.

\begin{tabular}{|c|c|c|c|c|c|c|c|c|}
\hline \multirow{2}{*}{\multicolumn{2}{|c|}{ Histopathological Finding }} & \multicolumn{4}{|c|}{ VEGF } & \multirow{2}{*}{\multicolumn{2}{|c|}{ Total }} & \multirow{3}{*}{ P-value } \\
\hline & & \multicolumn{2}{|c|}{ Positive } & \multicolumn{2}{|c|}{ Negative } & & & \\
\hline & & No. & $\%$ & No. & $\%$ & No. & $\%$ & \\
\hline \multirow{2}{*}{ Gender } & Male & 33 & 64.7 & 19 & 63.3 & 52 & 64.2 & \multirow{2}{*}{$0.901 *$} \\
\hline & Female & 18 & 35.3 & 11 & 36.7 & 29 & 35.8 & \\
\hline \multirow[b]{2}{*}{ Age } & $<60$ & 26 & 51.0 & 15 & 50.0 & 41 & 50.6 & \multirow{2}{*}{$0.932 *$} \\
\hline & $\geq 60$ & 25 & 49.0 & 15 & 50.0 & 40 & 49.4 & \\
\hline \multirow{3}{*}{ Tumor site } & Colon & 28 & 54.9 & 13 & 43.3 & 41 & 50.6 & \multirow{2}{*}{$0.315 *$} \\
\hline & Rectum & 23 & 45.1 & 17 & 56.7 & 40 & 49.4 & \\
\hline & Conventional AD & 38 & 74.5 & 27 & 90.0 & 65 & 80.2 & \multirow{4}{*}{$0.182 * *$} \\
\hline \multirow{3}{*}{ Histological Types } & Mucinous AD & 8 & 15.7 & 3 & 10.0 & 11 & 13.6 & \\
\hline & Signet ring cell AD & 5 & 9.8 & 0 & 0 & 5 & 6.2 & \\
\hline & Well & 2 & 3.9 & 0 & 0 & 2 & 2.5 & \\
\hline \multirow[t]{3}{*}{ Grade } & Moderate & 42 & 82.4 & 29 & 96.7 & 71 & 87.7 & \multirow[t]{2}{*}{$0.174 * *$} \\
\hline & Poor & 7 & 13.7 & 1 & 3.3 & 8 & 9.9 & \\
\hline & I & 1 & 2.0 & 8 & 26.7 & 9 & 11.1 & \multirow{4}{*}{$0.006 *$} \\
\hline \multirow{3}{*}{ TNM Stage } & II & 16 & 31.4 & 8 & 26.7 & 24 & 29.6 & \\
\hline & III & 31 & 60.8 & 13 & 43.3 & 44 & 54.3 & \\
\hline & IV & 3 & 5.9 & 1 & 3.3 & 4 & 4.9 & \\
\hline \multirow{3}{*}{$\begin{array}{c}\text { Local Invasive } \\
\text { Depth }\end{array}$} & $\mathrm{T} 2$ & 2 & 3.9 & 10 & 33.3 & 12 & 14.8 & \multirow{3}{*}{$0.001 *$} \\
\hline & $\mathrm{T} 3$ & 46 & 90.2 & 18 & 60.0 & 64 & 79.0 & \\
\hline & $\mathrm{T} 4$ & 3 & 5.9 & 2 & 6.7 & 5 & 6.2 & \\
\hline \multirow{2}{*}{ Lymph Nodes } & Non involved & 17 & 33.3 & 17 & 56.7 & 34 & 42.0 & \multirow{2}{*}{$0.040 *$} \\
\hline & Involved & 34 & 66.7 & 13 & 43.3 & 27 & 58.0 & \\
\hline \multirow{3}{*}{ Distant Metastasis } & M0 & 48 & 94.1 & 29 & 96.7 & 77 & 95.1 & \multirow{3}{*}{$1.000 * *$} \\
\hline & M1 & 3 & 5.9 & 1 & 3.3 & 4 & 4.9 & \\
\hline & & 51 & 100 & 30 & 100 & 81 & 100 & \\
\hline
\end{tabular}

\footnotetext{
* Chi square, **Fisher exact test. P-value is significant $P \leq 0.05$
} 
Other histological findings like desmoplastic reaction, lymphocytic, and macrophages infiltration in correlation with CGA and VEGF expression are illustrated in Table 5. Desmoplastic reaction had significant difference $(\mathrm{P}=0.003)$ with NED only. Other histological changes did not contribute to the expression of both CGA and VEGF in the tumor cells.

Table 5. Correlation of histological changes with neuroendocrine differentiation in CRC

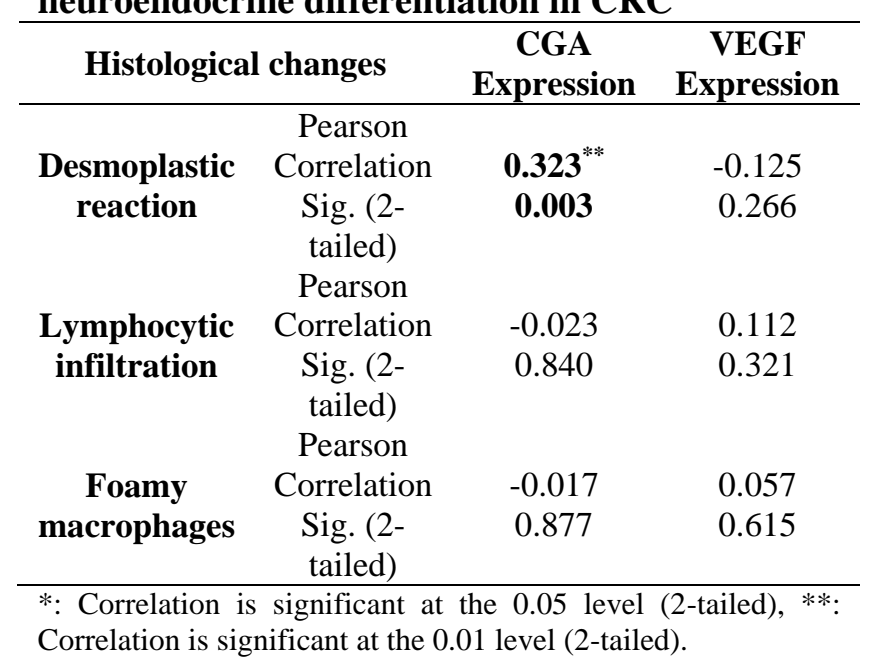

The relationship between NED and VEGF is shown in Table 6. About 26 cases $(32.1 \%)$ revealed positive expression of both NED and VEGF, whereas 17 cases $(21.0 \%)$ had negative cytoplasmic staining for both IHC markers. This means that concomitant correlation is $65 \%$ and the positive staining in both NED and VEGF increases about $11.1 \%$ than the negative expression, but this increasing; statistically did not have any impact $(\mathrm{P}=$ $0.506)$.

Table 6. Association of NED with VEGF in CRC

\begin{tabular}{|c|c|c|c|c|c|c|c|}
\hline \multirow{2}{*}{ VEGF } & \multicolumn{4}{|c|}{ NED } & \multirow{2}{*}{\multicolumn{2}{|c|}{ Total }} & \multirow{3}{*}{$\begin{array}{c}\text { P- } \\
\text { value }\end{array}$} \\
\hline & \multicolumn{2}{|c|}{ Positive } & \multicolumn{2}{|c|}{ Negative } & & & \\
\hline osi & $\begin{array}{l}\text { No. } \\
26\end{array}$ & $\begin{array}{c}\% \\
32.1\end{array}$ & $\begin{array}{c}\text { No. } \\
25\end{array}$ & $\begin{array}{c}\% \\
30.9\end{array}$ & $\begin{array}{c}\text { No. } \\
51\end{array}$ & $\begin{array}{l}\% \\
63\end{array}$ & \\
\hline & 13 & 16.0 & 17 & 21.0 & 30 & 37 & 0.506 \\
\hline tal & 39 & 48.1 & 42 & 5.1 .9 & 81 & 100 & \\
\hline
\end{tabular}

*Chi square. P-value is significant $P \leq 0.05$

\section{Discussion:}

There are many IHC markers used to demonstrate the expression of NED, like CGA, neuron specific enolase and synaptophysin (16). NED is not common finding in CRC; it can be used as a helpful marker for prognosis, especially after the surgical therapy (18). This study assessed the frequency of NED in tumor tissues, 42 cases were negative NED, while NED was expressed in 39 $(48.1 \%)$ cases. Gulubova and Vlaykova (19); Chen et al. (20) have detected NED differentiation in approximately $34.3 \%, 51.4 \%$ of colorectal cancer.

The study also assessed the frequency of NE cell hyperplasia in normal colonic mucosa nearby tumor, 34 cases were positive NE cell hyperplasia and 42 cases were negative.

In the present study the increasing number of NE cells in untransformed glands has marked correlation with the NED in colorectal AD. The NE cell hyperplasia in the normal glands may be the result from either observing or diffusing these granules in hyperplastic cells to the tumor cells, or from diffusing these granules from tumor cells toward the normal cells.

A number of hypotheses were proposed to detect the ancestry of NE cell hyperplasia and NE differentiation in CRC (21). They assumed that NE differentiation arises from cells containing neurosecretory granules known as 'amine precursor uptake decarboxylase' (22), which resulted from neural crest cells. La Rosa et al. (11) have mentioned that NE cells in the tumor are responsible for production of some growth factors. The NE cells in the tumor tissue exhibits some behaviors unlike those in the normal colon (19). According to abnormal behavior in tumor cells, NE cells are organized as adjacent to each other. Losing the 'Notch', which is the signal pathway of the cell surface protein, prevents adjacent cells from differentiating into NE cells by lateral inhibition in normal colonic cells (23).

Other studies attributed that this neuroendocrinal differentiation in CRC are produced as a result of final dedifferentiation of typical $\mathrm{AD}$, on the basis of 'divergent differentiation' model (24). This model postulates that $\mathrm{AD}$ cells give rise to neuroendocrinal differentiation in response to changes in the hormonal and growth factor of micro-environmental milieu by the process of trans-differentiation (25).

The restriction of NE cell hyperplasia with the inflammatory bowel disease and the longstanding inflammation probably represent prompting for endocrine cell growth (25).

In an antecedent study, the polypeptide hormones and biogenic amines that were produced in NE cell vesicles played a critical role in the growth regulation of intestinal epithelia in both normal and neoplastic tissues (26). El-Salhy et al. (27) proposed that in irritable bowel syndrome associated with inflammation, the immune cells will produce cytokines and other substances that make modulation in mature endocrine cell behavior and even in the stem cells of the gastrointestinal tract. As a result, this will affect the differentiation and colonogenic activities of these stem cells. 
Furthermore, the expression of certain hormones in mature endocrine cells will switch off and other unfavorable hormone productions will switch on. These changes will affect the proportion of different types of endocrine cells and the total density of NE cells.

The restriction of NE cell hyperplasia with the inflammatory bowel disease and the longstanding inflammation probably represent prompting for endocrine cell growth (28). Increased releasing of NE cells secretion is usually associated with inflammation of colonic mucosa. Also patients with inflammatory bowel disease are at increased risk of CRC (29). This situation has been mentioned by Wang et al. (30) in which they demonstrated that mice induced with colitis could result in neuroendocrine cell hyperplasia. Conversely NE cell hyperplasia could result from tumor cells that secret some growth factors, these growth factors liberated from tumor cells may enhance desmoplastic reaction and angiogenesis, and subsequently leading to symptoms appearance (11).

Many studies utilized the conceivable relation between the existence of $\mathrm{NE}$ changes (hyperplasia and differentiation) in colorectal carcinomas and the prognosis. In the present study tumor with distant metastasis correlated to poor prognosis $(\mathrm{P}=0.049)$, these findings are conformable with data of many authors like Chen et al. (20); Volante et al. (31); Liu et al. (32), in which they found that NED correlated to stage of tumor. Volante et al. (31) found that distant metastasis in CRC have more percentage of NED when compared to primary tumor.

Other findings haven't manifested a significant relationship between the presence of NED and the appearances of carcinoma and prognosis $(33,34)$. The number of cases used in this study played an important role, even the distribution number; as more than two thirds $(87.7 \%)$ of the patients had grade II tumor.

The biological mechanisms depended on poorly differentiated CRC from NED and metastasis remained inconspicuous. Theoretically, NED could induce the growth and the metastatic ability via the neurohormonal material secretion (20).

VEGF was positive in $63 \%$ in the current study. High expression of VEGF in colorectal carcinoma was recorded by Kamel et al. (14) with a percentage of 94.7. While Zlobec et al. (35) and Ismail (36) found that $47 \%$ and $61.81 \%$ had positive expression of VEGF in CRC, respectively.

Expression of VEGF relationships do not have any effects on clinicopathological factors like gender, age, location and the histological types of tumor, as well as tumor grade. However, there is correlation between VEGF with the TNM stage and the local and lymph node invasion. This situation is identical to what some authors have reached (14).

The VEGF is a positive regulator of angiogenesis; therefore, it plays a key role in tumor angiogenesis. This marker has been expressed with high percentages in several types of tumors including CRC $(14,37)$.

Furthermore, the relationship of histological changes with NED and VEGF in CRC was investigated. It was revealed that only desmoplastic reaction has an association with NED. This, perhaps, interprets the stimulation capacity via providing ground for the NED to grow and metastasize to other tissues of the body. The expression of VEGF was high $26(32.1 \%)$ in cases that showed NED, but this increasing was nonsignificant statistically $(\mathrm{P}=0.506)$. Tumors with positive expression for VEGF containing VEGFpositive NE cells have elevated ratio of vascularization, which perhaps participates to the unfavorable prognosis of patients (19). Ismail (36) cited that there was highly significant correlation between matrix metalloproteinases (MMPs) and VEGF expression in patients with CRC. The (MMPs) is a proteolytic enzyme of extracellular matrix which plays a role in degradation of various proteins of extracellular matrix selectively. This event could be supported by collagenases found in extracellular matrix component, especially interstitial collagenase matrix metalloproteinase -1 (MMP-1) (12, 38). Therefore, degradation in extracellular matrix proteins might assist for the easy transference of these growth factors.

\section{Conclusions:}

1. Neuroendocrine cell hyperplasia and neuroendocrine differentiation are frequently expressed in colorectal adenocarcinoma.

2. Hyperplasia of neuroendocrine cells may have strong linkage in pathogenesis of colorectal adenocarcinoma. It needs further study.

3. Neuroendocrine differentiation and vascular endothelial growth factor expression correlate with advancing stage of tumor and it can be used as an important parameter for poor prognosis of the colorectal adenocarcinoma.

\section{Authors' declaration:}

- Conflicts of Interest: None.

- We hereby confirm that all the Figures and Tables in the manuscript are mine ours. Besides, the Figures and images, which are not mine ours, have been given the permission for republication attached with the manuscript. 
- The author has signed an animal welfare statement.

- Ethical Clearance: The project was approved by the local ethical committee in University of Duhok.

\section{References:}

1. Mármol I, Sánchez-de-Diego C, Pradilla D A, Cerrada E, Rodriguez Y M. Colorectal carcinoma: a general overview and future perspectives in colorectal cancer. Int J Mol Sci. 2017 Jan; 18(1): 197.

2. Bernick PE, Klimstra DS, Shia J, Minsky B, Saltz L, Shi W, et al. Neuroendocrine carcinomas of the colon and rectum. Dis Col Rect. 2004 Feb; 47(2): 163-9.

3. Kleist B, Poetsch M. Neuroendocrine differentiation: The mysterious fellow of colorectal cancer. World $\mathbf{J}$ Gastroenterol. 2015 Nov; 21(41): 11740-7.

4. Massironi S, Zilli A, Cavalcoli F, Conte D, Peracchi M. Chromogranin A and other enteroendocrine markers in inflammatory bowel disease. Neuropeptides. 2016 Aug; 1(58):127-34.

5. Mori M, Mimori K, Kamakura T, Adachi Y, Ikeda Y, Sugimachi K. Chromogranin positive cells in colorectal carcinoma and transitional mucosa. J Clinc Pathol. 1995 Aug1; 48(8): 754-8.

6. Klöppel G, Anlauf M, Perren A. Endocrine precursor lesions of gastroenteropancreatic neuroendocrine tumors. Endocrine Pathol. 2007 Sep; 18(3): 150-5.

7. Bosman FT, Carneiro F, Hruban RH, Theise ND. WHO classification of tumours of the digestive system. World Health Organization, 2010; $4^{\text {th }}$ ed.

8. Shin SH, Kim SH, Jung SH, Jang JW, Kang MS, Kim SI, et al. High-Grade Mixed adenoneuroendocrine carcinoma in the cecum: A case report. Annals coloproctology. 2017 Feb; 33(1):39.

9. Woischke C, Schaaf CW, Yang HM, Vieth M, Veits $\mathrm{L}$, Geddert $\mathrm{H}$, et al. In-depth mutational analyses of colorectal neuroendocrine carcinomas with adenoma or adenocarcinoma components. Modern Pathol. 2017 Jan; 30(1):95.

10. Sabnis A, Carrasco R, Liu SX, Yan X, Managlia E, Chou PM, et al. Intestinal vascular endothelial growth factor is decreased in necrotizing enterocolitis. Neonat.. 2015; 107(3):191-8.

11. La Rosa S, Chiaravalli AM, Capella C, Uccella S, Sessa F. Immunohistochemical localization of acidic fibroblast growth factor in normal human enterochromaffin cells and related gastrointestinal tumours. Virch Archiv. 1997 Mar; 430(2): 117-24.

12. Khalid A, Javaid MA. Matrix Metalloproteinases: New Targets in Cancer Therapy. J Cancer Sci Ther. 2016; 8(6):143-53.

13. Ahmad A, Venizelos N, Hahn-Strömberg V. Prognostic Effect of Vascular Endothelial Growth Factor+ 936C/T Polymorphism on Tumor Growth Pattern and Survival in Patients Diagnosed with Colon Carcinoma. J Tumor Res. 2016; 2(1):1-6.

14. Kamel AA, Yossef WT, Mohamed M. Correlation of vascular endothelial growth factor expression and neovascularization with colorectal carcinoma: A pilot study. J Adenocarcinoma. 2016; 1(1): 5.
15. Ricci V, Ronzoni M, Fabozzi T. Aflibercept a new target therapy in cancer treatment: a review. Critical rev oncol / hematol. 2015 Dec; 96(3):569-76.

16. Kyriakopoulos, G, Mavroeidi, V, Chatzellis, E, Kaltsas, GA, Alexandraki, K I. Histopathological, immunohistochemical, genetic and molecular markers of neuroendocrine neoplasms. Ann Transl Med, 2018 Jun; 6(12). 1-13.

17. Shia J, Tickoo SK, Guillem JG, Qin J, Nissan A, Hoos A et al. Increased endocrine cells in treated rectal adenocarcinomas: a possible reflection of endocrine differentiation in tumor cells induced by chemotherapy and radiotherapy. Am J Surg Pathol. 2002 Jul; 26(7): 863-72.

18. Fondevila C, Metges JP, Fuster J, Grau JJ, Palacin A, Castells A, et al. p53 and VEGF expression are independent predictors of tumour recurrence and survival following curative resection of gastric cancer. Br J Cancer. 2004 Jan; 90(1): 206-15.

19. Gulubova M, Vlaykova T. Chromogranin A-, serotonin-, synaptophysin-and vascular endothelial growth factor-positive endocrine cells and the prognosis of colorectal cancer: an immunohistochemical and ultrastructural study. Journal of gastroenterology and hepatology. 2008 Oct;23(10):1574-85.

20. Chen Y, Liu F, Meng Q, Ma S. Is neuroendocrine differentiation a prognostic factor in poorly differentiated colorectal cancer. World J Surg Oncol. 2017 Dec; 15(1): 71.

21. Slovin SF. Neuroendocrine differentiation in prostate cancer: a sheep in wolf's clothing? Nature Rev Urol. 2006 Mar; 3(3): 138-44.

22. Schron D S, Gipson T, Mendelsohn G. The histogenesis of small cell carcinoma of the prostate an immunohistochemical study. Cancer. 1984; 53: 247880.

23. Schonhoff SE, Giel-Moloney M, Leiter AB. Minireview: Development and differentiation of gut endocrine cells. Endocrinol. 2004 Jun; 145(6): 263944.

24. Bonkhoff H. Neuroendocrine cells in benign and malignant prostate tissue: morphogenesis, proliferation, and androgen receptor status. Prostate. 1998; 36(S8): 18-22.

25. Sauer CG, Roemer A, Grobholz R. Genetic analysis of neuroendocrine tumor cells in prostatic carcinoma. Prostate. 2006 Feb; 66(3): 227-34.

26. Johnson LR. Regulation of gastrointestinal mucosal growth. Physiol Rev. 1988 Apr; 68(2): 456-502.

27. El-Salhy M, Solomon T, Hausken T, Gilja OH, Hatlebakk JG. Gastrointestinal neuroendocrine peptides/amines in inflammatory bowel disease. World J Gastroenterol. 2017 Jul; 23(28): 5068.

28. Nascimbeni R, Villanacci V, Di Fabio F, Gavazzi E, Fellegara G, Rindi G. Solitary microcarcinoid of the rectal stump in ulcerative colitis. Neuroendocrinol. 2005; 81(6): 400-4.

29. Barral M, Dohan A, Allez M, Boudiaf M, Camus M, Laurent $\mathrm{V}$, et al. Gastrointestinal cancers in inflammatory bowel disease: An update with 
emphasis on imaging findings. Critical rev oncol /hematol. 2016 Jan; 1(97): 30-46.

30. Wang H, Steeds J, Motomura Y, Deng Y, VermaGandhu M, El-Sharkawy RT, et al. CD4+ T cellmediated immunological control of enterochromaffin cell hyperplasia and 5-hydroxytryptamine production in enteric infection. Gut. 2007 Jul; 56(7): 949-57.

31. Volante M, Marci V, Andrejevic-Blant S, Tavaglione $\mathrm{V}$, Sculli MC, Tampellini M, et al. Increased neuroendocrine cells in resected metastases compared to primary colorectal adenocarcinomas. Virch Archiv. 2010 Nov; 457(5): 521-7.

32. Liu Y, He J, Xu J, Li J, Jiao Y, Bei D, et al. Neuroendocrine differentiation is predictive of poor survival in patients with stage II colorectal cancer. Oncol let. 2017 Apr; 13(4): 2230-6.

33. Suresh PK, Sahu KK, Pai RR, Sridevi HB, Ballal K, Khandelia $\mathrm{B}$, et al. The prognostic significance of neuroendocrine differentiation in colorectal carcinomas: our experience. J Clinic Diag Res: (JCDR). 2015 Dec; 9(12): EC01.

34. Hamada Y, Oishi A, Shoji T, Takada H, Yamamura M, Hioki K, et al. Endocrine cells and prognosis in patients with colorectal carcinoma. Cancer. 1992; 69: 2641-6.

35.Zlobec I, Steele R, Compton CC. VEGF as a predictive marker of rectal tumor response to preoperative radiotherapy. Cancer: Interdisci. Int $\mathrm{J}$ Am Cancer Soc. 2005 Dec; 104(11): 2517-21.

36. Ismail NH. mRNA in situ Hybridization Analysis of Vascular Endothelial Growth Factor and Matrix Metalloproteinase-1 in Colorectal Cancer. Al-Mustan. J Pharma Sci. 2016 Dec; 16(2): 62-9.

37. Eefsen RL, Engelholm L, Willemoe GL, Van den Eynden GG, Laerum OD, Christensen IJ, et al. Microvessel density and endothelial cell proliferation levels in colorectal liver metastases from patients given neo-adjuvant cytotoxic chemotherapy and bevacizumab. International journal of cancer. 2016 Apr; 138(7): 1777-84.

38. Lazaris A, Amri A, Petrillo SK, Zoroquiain P, Ibrahim N, Salman A, et al. Vascularization of colorectal carcinoma liver metastasis: insight into stratification of patients for anti-angiogenic therapies. The J Pathol: Clinic Res. 2018 Jul; 4(3): 184-92.

\section{مقارنة تمايز الغدد الصم العصبية مع الفرط النسيجي لتلك الخلايا وعامل نمو بطانة الاوعية الدموية في سرطان القولون والمستقيم
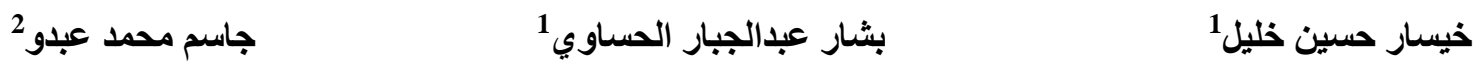

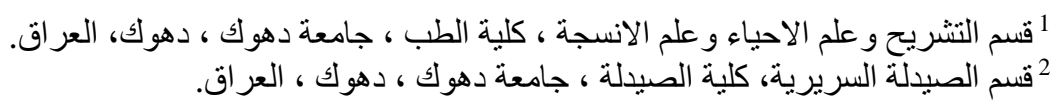

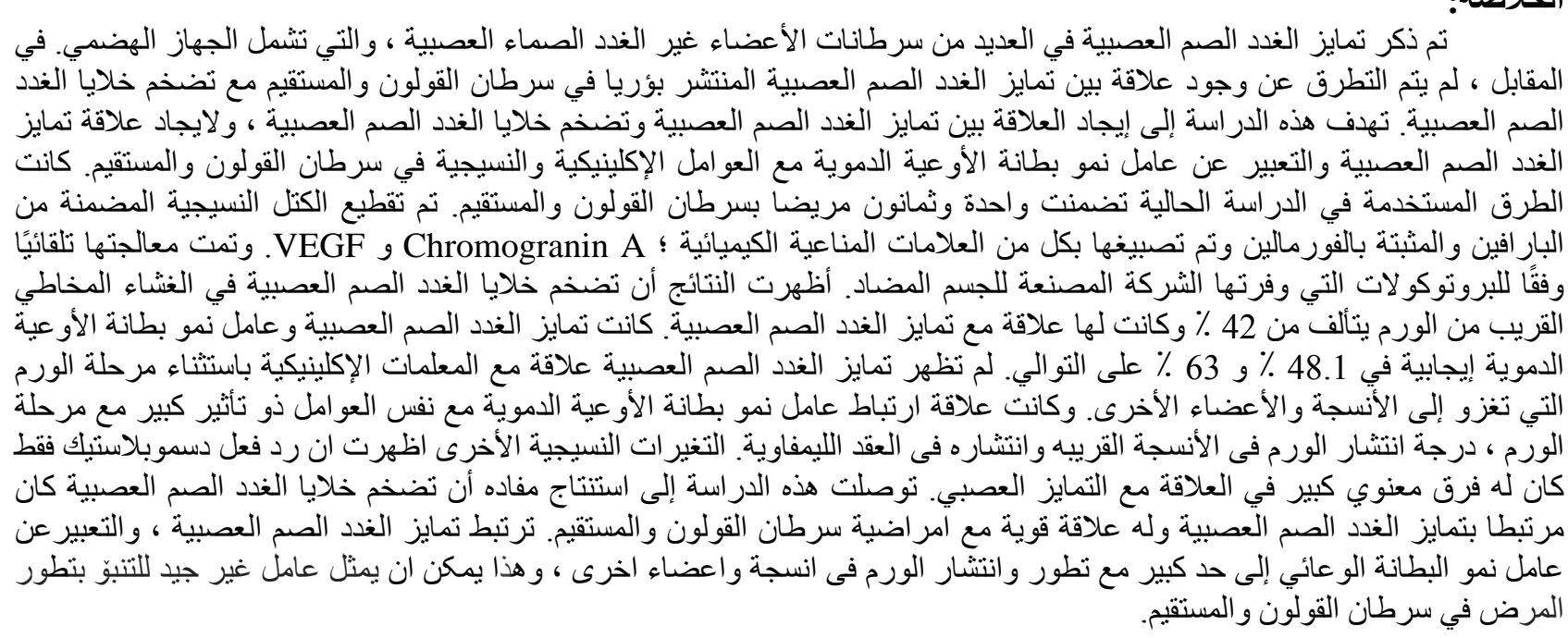

الكلمات المفتاحية: تضخم خلايا الغدد الصم العصبية، تمايز الغدد الصم العصبية، سرطان القولون والمستقيم، عامل نمو بطانة الأوعية 